\title{
On Moral Justifications for the Tort/Crime Distinction*
}

\author{
Robert W. Drane† \\ David J. Neal††
}

Most systems of justice distinguish criminal from tortious conduct. They respond to wrongs that are classified as criminal by deliberately mflicting pain ${ }^{1}$ on the wrongdoer through the institution of legal punishment. They respond to wrongs that are classified as tortious, on the other hand, with an attempt to restore injured parties to their positions before the wrong, by requiring that the wrongdoer compensate the victim. The reasons for this difference im treatmont are not obvious: it is conceivable that a system of justice might refrain altogether from inflicting pain dehberately by simply requiring that wrongs of any sort be compensated. Yet there is a moral dimension to this difference in treatment. Unless it can be justified, it is a violation of the fundamental moral mjunction against the needless infliction of pain. Systems that distinguish crimes from torts thus must identify those aspects of "criminal" conduct that justify punishing the offender rather than simply requiring him to pay money damages. ${ }^{2}$

Unfortunately, this question has aroused surprisingly little interest. The immense body of hiterature on punishment focuses primarily on whether the institution of legal punishment itself can be justified, ${ }^{3}$ and on what criteria must be met for a person to have "responsibility sta-

* We wish to thank Jules Coleman, Sanford Kadish, Sheldon Messinger, Philip Selznick, and Dick Wasserstrom for reading and criticizing a draft of this paper.

$\dagger$ B.A. 1969, University of Connecticut; M.A. 1971, University of Calgary; Candidate in Philosophy, University of California, Berkeley; first-year student, Boalt Hall School of Law, University of California, Berkeley.

†† B.A., LL.B. 1974, LL.M. 1977, University of Melbourne; graduate student in Jurisprudence and Social Policy, University of California, Berkeley.

1. Hart refers to pain or other unpleasant circumstances. Other writers refer to suffering and deprivation. We use pain as a shorthand term to incorporate references to all these terms. See H.L.A. Hart, Punishment and Responsibility 4-5 (1968).

2. It may be objected that, because many wrongful acts constitute both torts and crimes, the consequences of failure to justify the distinction are not serious. This objection is unfoundcd because society must justify treating those acts as both torts and crimes. If the offender is liable to pay compensation, and compensation is a morally sufficient response to a given form of conduct, then how is the additional burden of punishment to be justified?

3. See, e.g., T. Honderich, Punishment: The Supposed Justifications (1969); E. Pincoffs, the Rationale of Legal Punishment (1966); Rawls, Two Concep/s of Rules, in Ethics 104 (J. Thomson \& G. Dworkin eds. 1968); The Philosophy of Punishment (H. Acton ed. 1969). 
tus" such that he may be held liable for a criminal wrong. ${ }^{4}$ These theories seem to assume that the criteria for "criminal" conduct are known. Yet examination of the few atteinpts to elucidate criteria for criminal conduct reveals that they have only produced confusion. Writers in the area have atteinpted to distinguish between crimes and wrongs against conventional inorality, ${ }^{5}$ between crimes and public welfare offenses, ${ }^{6}$ and between crimes and torts. We focus on this third distinction.

We will examine four theories that have been advanced to justify the tort/crime distinction. The first theory bases tlie distmction on the idea tliat crimes are offenses to public interests whereas torts are offenses to private interests. The second claims that special types of harm distinguish crimes from torts. The third uses utilitarian arguinents based on deterrence and econornic efficiency to justify the distinction. Finally, Robert Nozick offers a justification that focuses on einotional states such as fear.

This Article defines a set of formal adequacy conditions for any attempt to justify the tort/crime distinction. It examines eacli of the four theories in light of those criteria, and concludes that of the four purported justifications, only Nozick's satisfies the formal adequacy conditions, although it fails to meet substantive requirements. It then reconstructs Nozick's arguinent in a way that renders it formally adequate and that reveals the fertility of arguments focusing on emotional states for justifications under various other inoral theories.

I

\section{The Criteria for an Adequate Moral Justification}

To justify is to provide reasons why a proposed belief, act, rule, course of conduct, or policy is correct. The reasons sliould be rationally presented, relevant, and impartial. ${ }^{7}$ What will count as an adequate justification depends on the circuinstances at hand and on a

4. See, e.g., H. Fingarette, The MEAning of Criminal Insanity (1974); Hospers, Free Will and Psychoonalysis, in Readings IN EthICAL Theory 633 (J. Hospers \& W. Sellars eds. 1970); Schlick, When is a Man Responsible?, in FreE WILL AND DETERMINISM 54 (B. Berofsky ed. 1966); Smart, Free Will, Praise, and Blame, in Determinism, Free WILl, AND MORAL ResponsiBILITY 196 (G. Dworkin ed. 1970).

5. See, e.g., P. Devin, The Enforcement of Morals (1965); H.L.A. HaRT, Law, LibERTY AND MORALITY (1963), in which the authors disagree on the subject of homosexuality between consenting adults. Hart argues that it is not a crime, while Devlin argues that it is. Both seem to assume that homosexuality is immoral. We do not wish to associate ourselves with that view.

6. See, e.g., P. Brett \& P. Waller, Criminal Law Cases and Material 566-68 (1962). Public welfare offenses included such things as the illegal sale of intoxicating liquor, sale of adulterated food or drugs, and sale of unbranded articles. See also Sayre, Public Welfare Offenses, 33 Colum. L. REv. 55 (1933).

7. For discussion of the question of justification, see S. BenN \& R. PEters, Social Princl- 
common understanding between the person offering the justification and his audience. In time of war, for example, a course of conduct may be justified by reference to the command of an officer. In less exigent circumstances, appeals to authority may not suffice, despite their expediency.

The tort/crime distinction requires a moral justification. Such a justification must, as a threshold matter, contain three elements: a moral theory to provide the justificatory force, interests to be protected or promoted by the distinction, and a rationale or argument by which it is shown whether and to what extent the moral theory allows protection or proinotion of those interests. These criteria are formal requirements, and we will refer to a justification that contams them as "ininimally adequate." A minimally adequate justification is, in other words, merely a justification of the right sort. A judgment that a justification is miniunally adequate will leave open the question whether it is substantively correct, that is, whether its inoral theory is consistent with our moral intuitions, whether it has accounted adequately for the interests involved, and whether its argument is valid and consistent both with facts about the world and with the moral theory. We will refer to justifications that are successful in these respects as "fully adequate."

The first element of a ininimally adequate moral justification is a inoral theory. The requisite moral theory would provide "ultimate moral principles" that justify the lower order moral rules that serve as a basis for particular moral judgments. It would provide a conception of "the good" at the most general level. Moral theories fall primarily into three categories. Libertarian theories emphasize the primacy of the individual and seek to protect individual rights and unconstrained choice. These theories set limits on the kinds of rules that are morally acceptable. Utilitarian theories argue that right actions are those that proinote the greatest utihty. "Utility" generally is defined in terms of such inental states as happiness, pleasure, or preference satisfaction. These theories direct the einployment of certain rules. Theories of the third type incorporate both the utilitarian concern for the general welfare and the libertarian concern for individual rights. These theories are confronted by the difficult question of how much utility a rule must provide to justify enacting it despite the fact that it overrides individual rights.

The second element of a minimally adequate moral justification is comprised of the interests to be protected. There is a sense in which certain very abstract interests are incorporated into any moral theory inasmuch as it describes the good. Thus, for example, utilitarianism

PLes and the Democratic State 30-34 (1959); J. Rawls, A THEORY OF Justice 17-21, 577-86 (1971). 
incorporates the interest in being happy, while libertarianism incorporates the interests that are protected by those rights whose violation it prohibits.

However, by themselves, such abstract interests cannot form the basis for the justification of any particular rule. For exanıple, identification of the interest in being happy will be relatively unimformative in a justification of the rule that a driver inust signal before turning. Thus, we refer to "interests" in a more particular sense as those things that motivate us to act in certain ways. These interests may fall within a broad spectrum, including the interest in being free front fear as well as the interest in the season record of the Oakland Raiders. A minimally adequate moral justification of a particular rule inust identify the particular interests that are protected or promoted by that rule.

The third elenent of a minimally adequate justification is an arguneent that a proposed or actual rule protects the interests at stake without violating the constraints of the inoral theory. The argument must introduce facts about human nature and the world, e.g., the sorts of prohibitions that will provide effective deterrence to undesirable courses of action, or the kinds of events that people fear. The argument then must combine the directives and constraints imposed by the moral theory and the interests to be served with these facts about the world. This will enable us to take the moral theory out of the realm of the purely abstract and to furnisli concrete social rules or analyze the moral acceptability of existing social rules or societal structures. ${ }^{8}$

Although this set of formal adequacy conditions leaves the substantive validity of any particular justification unspecified, it does provide advantages. Recognition of the elements required for minimal adequacy allows us to identify the particular areas of disagreement between competing views about how to categorize wrongful acts. In particular, these criteria help us to determme whether those disagreements result from diverse moral theories, from different beliefs about the facts, or froin a difference in focus in the rationales linking the facts and the nioral theory.

Furthermore, the criteria assist in identification of those areas in which empirical research is required. Thus, for example, we might determine that prohibition of fear-producing acts would be consistent

8. Benn and Peters have written in relation to moral justification:

[R]ules of a very high order of generality-at the level at which we speak of "principles of procedure"- define the teruns of discussion, rather than provide unique and unambiguous prescriptions for particular cases. They indicate the sort of criteria that will be admitted as relevant. For this very reason they can appear strikingly important in a very wide variety of situations. Precisely because they are formal rather than substantive and specific, they are at least tied to particular circumstances.

S. BENN \& R. PETERs, supra note 7, at 300. 
with our moral theory. In order to justify such prohibition, we would need to adduce evidence that fear has a deleterious effect upon people and that they therefore may be said to have an interest in being free from fear. Further research would then be required to discover which particular acts people fear in order to formulate the justifiable rule prohibiting such acts.

II

\section{Examination of Three Traditional Theories of the TORT/CRIME Distinction}

\section{A. Public and Private Interests}

The manifest difficulties involved in developing an adequate justification for the tort/crime distinction have driven many of those who have written on the subject to fall back on purely formal definitions of crime and tort. Blackstone's traditional definition of crime as "an act committed, or omitted, in violation of a public law, either forbidding or comınanding it" is a good example. ${ }^{9}$ These definitions rely on the law as their authority and do not provide any substantive reasons or justifications for the categorization found in the law. Such bare appeal to authority does not meet any of the criteria for an adequate inoral justification. ${ }^{10}$

Blackstone attempted to couch his definition as more than an appeal to authority by arguing that crime involves harm to public interests while tort involves only the interests of individuals. " This argument, however, also fails to meet the criteria. It does not identify a moral theory that prescribes limits withm which public interests may be protected by punishinent rather than by the exaction of coinpensation. Moreover, it fails to identify adequately the interests to be protected. The distinction between public and private interests is highly problematic. For instance, Roscoe Pound has argued that public and private interests are correlatives: an individual's private interest in the finality

9. 4 W. Blackstone, Commentaries *5. See also C. Kenny, Outlines of Criminal. Law I-27 (15th rev. ed. 1936); J. Michael. \& M. Adler, Crime, Law and Social Science 1-5 (1933); H. Packer, The Limits of the Criminal Sanction (1968).

10. Arguments of this sort drove so respected a commentator as Henry Hart to write: If one were to judge from the notions apparently underlying many judicial opinions, and the overt language even of some of them, the solution to the puzzle is simply that a crime is anything which is called a crime, and a criminal penalty is simply the penalty provided for doing anything which has been given that name. So vacant a concept is a betrayal of intellectual bankruptcy.

Hart, The Aims of the Criminal Law, 23 L. \& Contemp. Prob. 404 (1958). We note that intellectual bankruptcy is hardly the only problem: given the ethical dimensions of this question, our moral creditors might also have cause for conceru.

1.1. 3 W. Blackstone, Commentaries *2. See also J. Hall, General Principles of Criminal Law 240-46 (2d ed. 1960). 
of a particular contract may be restated as a public interest in the security of transactions. ${ }^{12}$ Thus, the labels "public" and "private" nnay attach to different aspects of the same interest. Plainly, in the absence of the first two elements of a minimally adequate justification, the third cannot exist, and Blackstone's argument has therefore failed entirely to meet the criteria.

Yet the public/private distinction appeals to intuition and experience. There is something meaningful in the notion that some public interests are so important that society should use its inost drastic sanctions to protect them. For example, intuition does not suggest that the public interest in the security of transactions is so important that society should use the criminal law to protect it. We need to "unpack" the moral intuitions behind the public interest label and examine those intuitions in light of our moral theory. ${ }^{13}$

\section{B. Harm}

Mill's famous argument that interference with an individual's freedom of action is only warranted when his actions will cause harn to others ${ }^{14}$ provides the starting point for theorists who argue that crimes are characterized by the type of harm done by the actor. ${ }^{15}$ Examination of these theories reveals, however, that they fail to satisfy the criteria for a minimally adequate justification because they focus exclusively on the second requirement, the imterests to be protected.

The concept of harm is deceptively simple. On the surface, it seens quite tangible. Yet, a moment's refiection reveals that it is altogether too abstract a concept to function effectively as the defining characteristic of a criminal wrong. It must be distmguished from the related concept of injury. A person may suffer harm without suffering physical or economic injury, as, for example, when a victim of defamation suffers harm to his reputation. Moreover, there are many cases of physical or economic injury that would not be regarded as harms, primarily those where the injury is caused by an inanimate object or is the

12. 3 R. Pound, JuRISPRUdENCE 23-24, 328-30 (1959).

13. See Parts III and IV infra.

14. Mill, On Liberty, in UTILITARIANISM 126 (M. Warnock ed. 1962).

15. See, e.g., Kleinig, Harm and Crime (1975) (unpublished paper delivered at the Australian National University). A substantially amended version of this paper appears as Crime and the Concept of Harm, 15 AM. PHILOsopHICAL Q. 27 (1978); however, much of our discussion is based on the earlier work. See also J. Feinberg, Social Philosophy 25-31 (1973); H. Gross, A TheORY OF CRIMINAL Justice 115-27 (1979); Eser, The Principle of "Harm" in the Concept of Crime: A Comparative Analysis of the Criminally Protected Legal Interests, 4 DuQ. L. Rev. 345 (19651966); Schulhofer, Harm and Punishment: A Critique of Emphasis on the Results of Conduct in the Criminal Law, 122 U. PA. L. Rev. 1497 (1974); Seney, "A Pond as Deep as Hell"-Harm, Danger and Dangerousness in Our Criminal Law (pts. I-2), 17-18 WAYNE L. Rev. 1095, 569 (1971-1972). 
result of an accident. For example, we commonly speak of a person as being injured, rather than harmed, by a falling rock or by a sudden decline in the stock inarket. Use of the term "harm" is usually reserved for cases in which the act of a person is involved. ${ }^{16}$

A second problem is to identify the nature of the imtent an actor must have in order to say that he has "harmed" someone. Intentional infliction of pam on another is not always harmful, as, for exainple, where a dentist repairs a tooth. The infliction of this pain is necessary to the well-being of the patient and therefore is justified. On the other hand, an unintentional but extremely neghigent act may be regarded as harmful. Underlying these differentiations is a moral assessment of the results of conduct in which the intention of the actor and the justification for the conduct are the salient factors.

Thus, the analysis so far has focused on the actor. Yet it is also clear that the victim is important. Since, as we have argued, the concepts of harm and injury are not congruent, most writers have sought to elucidate a conception of harm based on the impairment of certain relevant interests of the victim. ${ }^{17}$ Of course, certain interests could be impaired without the victim's knowledge, as, for example, where a person's house is burglarized. ${ }^{18}$ Under this conception, then, harm would be distinguished from cognate terms like "hurt" and "pain," since these cannot occur without the victim's knowledge.

This brief examination of the concept of harm should suffice to unmask its apparent simplicity. Without claiming precision, we can distinguish it from the related concepts of hurt, pain, and injury as follows: harm involves (1) the intentional or negligent acts of moral agents that interfere with the interests of some other person, and (2) an evaluation of the interference resulting in the conclusion that it was unjustified.

This characterization, however, merely forces reconsideration of the question originally presented: What are the interests to be protected by the crimmal law? Plainly, not every case of harn is appropriate for the criminal law. Damage to reputation as the result of defamation, for example, is not treated within the ambit of the crimmal law in most cases; ${ }^{19}$ yet, the defamed person has suffered a harm. Intu-

16. It is less clear whether the person has to be a rational moral agent. What if he is insane? Perhaps we would say that an insane person does cause harm but is precluded from responsibility status.

17. For a discussion of these interests, see J. Feingerg, supra note 15, at 26.

18. Id. at 27.

19. In times when honor and reputation were more prominent social values, the consequences of defamation were more serious. Speaking of criminal libel, Judge Lush said, "It is ranked amongst criminal offenses because of its supposed tendency to arouse angry passions, provoke revenge, and thus endanger the public peace...." The Queen v. Holbrook, 4 Q.B.D. 42 , 
itively, this sort of harm does not constitute a crime. Explanation of this imtuition requires the development of a hierarchy of harms.

Kleinig attempted to develop such a hierarchy by defining harm in terms of interference with another's imterests. He proposed that we view harm as the "inpairment" of welfare interests. ${ }^{20}$ One obvious problem with this definition is that the concept of impairment could mclude unintentional, accidental, or nonnegligent acts, and therefore the definition conflicts with the notion that the culpability of the interference is a precondition to the invocation of the term "harm." "Impairinent" is certamly too inclusive a term to differentiate criminal from other types of harm, as Kleinig himself seems to indicate when he discusses substituting "violation" for "impairment."21

A more significant problem with Kleinig's proposal is that the notion of welfare interest ${ }^{22}$ does not work as a criterion for ranking interests. It does not account for the defaination example given above. Why is the victim's interest in his reputation not a "welfare interest"? Moreover, any criterion such as that chosen by Kleinig will encounter the significant difficulty of accounting for multiple descriptions of the same act. Consider a trivial interest at the bottom end of a hierarchy of harms, for example, the interest in playing cricket. Suppose that a person intentionally steps in and unjustifiably prevents anotlier from playing cricket. Now, what seemed a relatively minor interest has been transformed into an extremely important one: the interest in personal liberty. It may be objected that the interest was mischaracterized and slould have been described as an interest in personal liberty in the first place. But a single activity almost always involves inore than one interest. Thus, there is an inherent difficulty in developing a satisfactory hierarchy of harms that will indicate whicl harmful acts are to be treated as criminal and which as inerely tortious.

Even assuming that a satisfactory hierarchy of harms could be developed, this justificatory theory would encounter a further difficulty: in order to constitute a crime, an interference with another's interests inust be unjustified. But what constitutes an unjustified interference? The justification based on harm lacks a moral theory that will delimit

46 (1878). On the question of anger, revenge, and the public peace as possible bases for crimmal prohibition, see Part IV infra. A more recent English case awarded punitive damages where a publishing company had calculated that its expected profit from a defamatory book would exceed the amount of compensation it would be required to pay. Cassell \& Co. Ltd. v. Broome, 2 W.L.R. 645 (1972). For a discussion of the role of deterrence in justifications for punishment, see Part IIC infra.

20. Kleinig, Crime and the Concept of Harm, supra note 15, at 33.

21. Id. at 32-34.

22. Id. at 30-32. Kleinig gives the following examples of welfare interests: "bodily and mental health, normal intellectual development, adequate material security, stable and non-superficial interpersonal relationships and a fair degree of herty." Id. at 31. 
those interferences that are unjustified. Absent such a moral theory, the justification remains incomplete.

Thus, the justification based on harm proves madequate. Because the concept of harm itself is not fully worked out, the justification fails to identify properly those interests that are to be protected by the tort/crime distmction. Moreover, it lacks justificatory force because it fails to provide a moral theory that would specify the limits within which those interests could be protected.

\section{Utilitarian Justifications}

Utilitarian theory suggests two different justifications for the tort/crime distinction. Both take the utilitarian nnoral theory as their starting points; thus, both must show that the interests to be promoted by the distinction will optimize happiness.

The first justification uses economic efficiency to distinguish criminal from tortious acts. ${ }^{23}$ In cases where violations of rights do not involve great harm or injury and do not occur too frequently, it may be inore efficient to put the onus on the victim to detect when a violation has occurred and present the case for compensation. Indeed, im cases where it is exceedingly difficult to detect whether a particular wrong has occurred, the victim nay be the surest guardian of his own rights because he is the inost sensitive to such violations. Therefore, it may be argued, since it is more efficient to abstain from public enforcement, redress $\mathrm{m}$ the civil courts is the inost appropriate response to such violations. Torts would be distimguished from crimes insofar as the former are those wrongs whose occurrence is exceedingly costly to detect.

This arguinent lacks two of the elements necessary to a minimally adequate justification: the interests to be protected, and the argument showing the extent to which they may be protected under utihtarian theory. Economic efficiency inay be one of society's general interests, but it is not one that is affected by the response to the wrongdoer once his crime has been detected. It inight arguably be more efficient to require the victim to function as police and prosecutor; however, this does not justify an assumption that the appropriate response to the violator would be merely to extract coinpensation from him without imposing criminal penalties. Moreover, because civil courts can, in many cases, award punitive damages, placing the victim's redress im the civil courts will not obviate the possibility of quasi-crimmal treatment of the wrongdoer. The arguinent thus is directed solely to enforcement proce-

23. This justification is suggested by some recent discussion of economic approaches to the issue of private enforcement. See, e.g., Becker \& Stigler, Law Enforcement, Malfeasance, and Compensation of Enforcers, 3 J. LEGAL STUD. 1 (1974); Landes \& Posner, The Private Enforcement of Law, 4 J. LEGAL STUd. 1 (1975). 
dures and does not justify any particular difference in treatment between wrongdoers.

Economic efficiency thus cannot function as the interest to be proinoted by the tort/crime distinction. The question therefore remains: Which interests are to be promoted by the distinction? While the argument suggests a method of efficiently promoting some interests, it fails to specify those interests.

A second utilitarian justification for the distinction focuses on deterrence. ${ }^{24}$ In situations where there is a strong interest in minimizing the number of wrongful acts and where it is very difficult to identify and apprehend the violators, the threat of having to pay full compensation for all costs occasioned by the wrong would not sufficiently deter the wrongful acts. The rational would-be wrongdoer could be expected to weigh the likelihood of gain from his contemplated action agamst the likelihood of apprehension and the costs he would incur if apprehended. Certainly, if compensation is the only cost in the balance, rational wrongdoers seeking to inaximize gain would not be deterred. Thus, where deterrence is important and apprehension is uncertain, the additional cost of criminal penalties is required.

This justificatory theory is incomplete because it fails to identify the situations in which there is a strong interest in deterrence. In other words, it lacks the second element of a minimally adequate justification. Even granting that there might be imterests so strong that we would wish to deter interference with them, and that the argument given would justify treatimg such interference as criminal, the justification fails unless those interests are identified.

Moreover, any justification based on utilitarian theory will encounter difficulties when it is being evaluated for full adequacy. Most persons do not accept the utilitarian moral theory in its entirety, but rather show considerable concern for individual rights. Utilitarian theories too readily require the sacrifice of innocent people where that sacrifice would pronote greater utility. Moreover, they require that each individual always act so as to promote the maximum amount of good, and they thus treat individuals as instruments througl which maximal utility is realized, rather than as autonomous creatures who have their own projects and plans for life. Such extreme interference with individual ends and concerns runs contrary to the moral intuitions of inost people in our society.

A second barrier to full adequacy for utilitarian justifications of the tort/crime distinction concerns the facts that any such theory must

24. See, e.g., T. Honderich, supra note 3, at 60-77; Mabbott, Punishment, in The PhilosoPHY of Punishment, supra note 3, at 39; E. PincoFfs, supra note 3, at 17-50; Rawls, supra note 3, at 104. 
marshal. It is notoriously difficult, for example, to measure those things that utilitarianism tells us ought to be maximized. Thus, it is difficult in any given situation to determme whether even the fundamental utilitarian interest in happimess will in fact be promoted by a given action. A inore particular factual problem for the deterrence argument is that it assumes that criminal penalties have a deterrent effect, an assumption on whicl experience casts grave doubt.

Thus, none of the three traditional justifications for the tort/crime distinction is adequate. We therefore turn to the justification offered more recently by Robert Nozick.

\section{III}

The Tort/Crime Distinction in Nozick's Minimal

STATE

\section{A. Nozick's Moral Theory}

Nozick's Anarchy, State and Utopia ${ }^{25}$ espouses a libertarian moral theory that stresses the preeminence of individual rights and explores the legitimate functions of a state within such a inoral framework. Nozick argues that the rights to life, health, liberty, and property possessed by each individual in the Lockean State of Nature ${ }^{26}$ form a "boundary" around each individual that may not be crossed by others without the individual's consent. That violation of these rights is impermissible even when violation would promote greater good or would prevent great harm ${ }^{27}$ reflects, Nozick argues, the Kantian notion that it is inorally necessary to treat individuals as ends in themselves and never merely as means to soine other end. ${ }^{28}$ Individual rights are sacrosanct, and their violation can never be justified by reference to any beneficial consequences accrumg from such violation. Nozick uses the term "side constraint" to express the proscription against violating individual rights. ${ }^{29}$

Under the theory of side constraints, moral rules are comprised exclusively of various prohibitions against violations of the rights of others. Whether an act is morally permissible depends entirely on whether it accords with the rules specifying which acts would trespass on the rights of another. ${ }^{30}$ Thus, the only actions that inay be prohibited are those that cross the borders of another; all other actions are protected froin interference by the actor's own rights.

25. R. Nozick, Anarchy, State and Utopia (1974).

26. Id. at 10,57 .

27. Id. at $30-35$.

28. Id. at 30-32.

29. Id at 28-35.

30. Id. at 29 . 


\section{B. Nozick's Justification for the Tort/Crime Distinction}

Nozick considers the possibility that the minimal state could respond to all boundary crossings with a simple requirement that the transgressor compensate his victim. Indeed, under libertarian theory, the decision how to respond to the border-crosser must take into account the rights of the border-crosser. A person who violates the rights of another cannot be said to have forfeited all of his own rights by his action; thus, a strict libertarian would respond to a rights-violator in the way that least interfered with the liberty of the violator, yet was a sufficient response to the violation.

Nozick thus confronts the question whether exaction of compensation alone will be a sufficient response to violations. ${ }^{31} \mathrm{He}$ argues that, even assuming a system that assures collection of coinpensation awards, there will be two categories of actions for which compensation will not be an adequate response: actions that mflict injuries that are not compensable, and actions that produce general fear. ${ }^{32}$ These types of actions, he argues, should be prohibited on pain of pumshment.

The second category focuses on the uncompensated victims of what we term "general fear." Nozick contends that there are certaim actions, typically those that inflict personal mjury, that we fear even though we may know that we will be compensated fully for the injury if and when it is inflicted. Thus, for example, if I know that sometime in the commg month my arm will be broken, I will be nervous and fearful despite my knowledge that I will receive full compensation for this in-

31. Nozick confronts this question in the context of his attempt to demonstrate that, contrary to the anarchist position, a minimal state can come into existence without violating the rights of those it purports to protect. Id. at 52. See generally id. at 88-120. Nozick conceives of the minimal state as something resembling a large private protection agency whose function is to protect each of its members from violation of their rights by others within and without the agency, and to extract compensation and/or impose punishment on violators. He refers to a protective group that does not have a monopoly on power as a "dominant protection agency" (DPA). Id. at 108-13. The difficulty, as Nozick sees it, is to move from a DPA to a minimal state (with a monopoly on power) without violating the rights of those who cannot or will not join the protection agency but insist on enforcing their own rights privately. Id. at 54-56. To simply insist that they join, backing the insistence with force if necessary, would do violence to his program.

Nozick attempts to solve this dilemma by showing that it is morally acceptable to prohibit "risky conduct." Id. at $82-83,114$. He argues that private enforcement of one's rights, especially where the reliability of one's enforcement procedures is unknown, imposes a risk upou all those who may be adversely affected. Id. at $88-101,105$. Thus, it is permissible for the DPA to prevent anyone, including nonjoiners, from privately enforcing their rights. Id. at 110 .

It is important to note that the minimal state will forbid risky activities under the threat of punishment. It will not allow nonjoiners to enforce their own rights even provided they pay compensation if their response is excessive or is dirccted at an innocent person incorrectly identified as the transgressor. $I d$. at 110,114 . In order to justify this restraint, Nozick must introduce a theory that gives an account of when it is proper to respond to boundary crossings with the demand for punishment and when the extraction of compensation alone is a morally sufficient response.

32. Id. at 65-66. 
jury. By contrast, I will not suffer any fear from the knowledge that my car will be damaged and that I will be fully compensated. ${ }^{33}$ If I believe that the system in which I live permits people to break my arm provided that they pay compensation, I will suffer fear: I will fear being victimized by such actions.

Thus, the prohibition agamst fear-producing acts is not addressed to the fear of a person who is actually injured. That fear could be compensated. Rather, it seeks to protect the other members of society from the fear that they will suffer if such actions are allowed subject to the requirement of compensation. This fear cannot be compensated: it would be unfair to extract compensation from the transgressor in any individual case (e.g., an assault) for the general fear suffered by those not directly involved, smce the individual transgressor did not cause that fear. Rather, it is the knowledge that the system allows such acts that causes the fear. ${ }^{34}$ Thus, the uncompensated general fear gives rise to a "legitimate public interest" in prohibiting fear-producing actions. It provides, Nozick says:

one dimension of a distinction between private wrongs and wrongs having a public component. Private wrongs are those where only the injured party need be compensated; persons who know they will be compensated fully do not fear them. Public wrongs are those people are fearful of, even thougl they know they will be compensated fully if and when the wrongs occur. ${ }^{35}$

This argument has a decidedly utilitarian flavor inasmuch as it gives great weight to the consequences of fear-producing actions on persons who are not themselves victims of a particular transgression. Nozick states that once consideration has been given to the effects and consequences of not prohibiting fear-producmg actions, it is "obvious" that they justify prohibiting individuals from engaging in such actions. Nozick does not specify what those effeets and consequences might be, yet he considers tliem sufficiently important to require deterrence of the actions that produce them. He says:

[O]ur argument for prohibiting certain actions, such as assaults, assumes that merely to require an attacker to compensate his victim for the effects of the attack [though not for any general anticipatory fear] would not sufficiently deter attacks so as to leave people unfearful. The argument from fear fails if that assumption is mistaken. ${ }^{36}$

\section{Evaluation of the Adequacy of Nozick's Justification}

Nozick's justification for the tort/crime distimction meets the erite-
33. Id. at 66-67.
34. Id. at 66,68 .
35. Id. at 67.
36. Id. at 68-69. 
ria for ininimal adequacy: it atteinpts to argue that an interest in freedom from fear may be protected within the libertarian moral theory. However, assessment of the justification in light of the criteria for full adequacy reveals that it is deficient in two respects: (a) the third element of the justification is incomplete masmuch as it does not spell out in sufficient detail the effects and consequences of allowing fear-producing actions; and (b) an argument along the lines suggested by Nozick, even if elaborated, would almost certainly be irreconcilable with his hibertarian noral theory.

It is apparent that Nozick intends that his justification for the tort/crime distinction will protect an interest in being free from fear. However, his argument for such protection is fraught with difficulty. It should be recalled that, under libertarian theory, the only actions that may be prohibited on pain of punishment are those (a) that constitute violations of Lockean rights, and (b) for which compensation is an inadequate response, either because the injuries they inflict are not compensable or because compensation alone will not adequately protect the interests at stake. Nozick contends that compensation is an inadequate response to actions that cause fear; however, there is no warrant in his argument for the assertion that acts that cause general fear constitute border-crossings. In order to claim that the victims of general fear suffer border-crossings, one would have to posit a right not to be fearful or apprehensive. Nozick nowliere explicitly posits such a right, although at times he seems to imply that it exists. ${ }^{37}$ It certainly is not among the Lockean rights. It might be possible to subsume such a right under one of the Lockean rights, but Nozick makes no such argument.

Moreover, Nozick would encounter insurmountable difficulties in advancing an argument for a right to be free from general fear. Under Nozick's libertarian principles, the violation of any right must be redressable, either through compensation or prohibition. But examination reveals that a "right" to be free from fear could not be vimdicated in either fashion.

If compensation is the proposed remedy, it becomes necessary to identify the appropriate source of compensation for those whose "right" to be free from fear had been violated. Although Nozick con-

37. Id. at 68. In fact, he probably could not make such a claim consistently with his overall program. The context of Nozick's effort to justify the tort/crime distinction was an attempt to justify prohibition of self-enforcement of rights by those who refused to join the minimal state. Nozick argued that self-enforceinent of rights would cause general fear im the population because of the unrehability of unknown enforcement procedures. See note 31 supra. If Nozick were to regard such general fear-producing acts as border crossings, he would be forced to admit that the proper enforcement of one's own rights could in itself be a violation of another's rights. This would be inconsistent with basic hibertarian theory. 
siders this question, ${ }^{38}$ he does not suggest any answers. It would be unfair to require that the individual transgressor coinpensate because, as we saw above, he is not the cause of the general fear. Since the state causes the general fear by allowing fear-producing acts, perhaps the state should coinpensate. However, it is unlikely that Nozick would consider compensation by the state to be an option for the libertarian. That is, a systein organized on libertarian principles probably could not collect a tax froin all ineinbers to pay for the coinpensation. People who do not engage in fear-producing actions could object to being deprived of their property in order to pay for those who do. A libertarian is precluded from arguing that this is a cost of belonging to the system by his insistence on the primacy of individual rights. Possibly a tax on those who do engage in fear-producing actions would neet the case, but it would be enorinously expensive for those people, and would becoine increasingly expensive as those who could not pay ceased to engage in such acts. It would appear, then, that compensation would not be a viable response to violations of the "right" to be free from fear. The only possible protection for such a right would tlerefore be prohibition on pain of punishment.

But prohibition on pain of punishment for fear-producing acts would also be deeply problematic. It should be recalled that, in Nozick's view, general fear is not produced by any imdividual transgressor; rather, its existence depends upon the belief that the state will tolerate those acts provided compensation is paid. ${ }^{39}$ Thus, even if Nozick posited a right to be free from general fear that could be protected by criminal sanctions under the hibertarian theory, there would be a significant problem in identifying the transgressor. No single offender can produce the fear; the state, if anyone, must be the transgressor. But Nozick conceives of the state as inerely a collection of individuals. It has no separate rights or identity of its own. It is thus difficult to see how the state could be a violator if its individual nembers are not. And it is illogical to state that there can be a violation but no violator.

Once it is seen that the production of general fear is not a rights violation under Nozick's theory, it becounes clear that his argument for the tort/crime distinction is inconsistent with his moral theory. As we

38. And who will compensate all the other apprehensive persons, who didn't happen to get assaulted, for their fear? . . . Would this defect of the system be avoided by someone who announced he would do a certain act at will, and not only would he compensate all of his victims, if any, but he would also compensate everyone who felt fear as a result of his announcement, even though he hadn't actually done the act to them?

R. Nozick, supra note 25 , at 66,68 . Nozick answers the last question in the negative.

39. See text accompanying note 33 supra. 
have shown ${ }^{40}$ Nozick's argument focuses on the consequences of fearproducing acts for the individual meinbers of society. This is inadmissible under hibertarian theory: the consequences of an individual's acts are only relevant insofar as they are rights violations. Nozick's argument that punishment is necessary to deter fear-producing acts is a purely utilitarian one as long as he is unwilling to posit a right to be free from fear.

Thus, Nozick has presented an inadequate justification for the tort/crime distinction. His work does, however, point the way toward some fruitful use of the concept of fear in an adequate justification. We shall explore this possibility in the next sections.

\section{Nozick's Argument from Fear Reconstructed}

The libertarian theory imposed strict limitations upon the sorts of actions that could be crimmalized. Nozick's argument fron 1 fear failed because he tried to exceed those limitations. The concept of fear should not, however, be discarded too hastily. It is possible to construct a libertarian-based argument for the tort/crime distinction that uses the concept of general fear.

The argument nust begin with the proposition that only those actions that violate the Lockean rights of others inay be prohibited. And, furtherniore, only a subset of those actions niay be prohibited: actions for which coinpensation is an inadequate response. We therefore inust consider when compensation will be an madequate response to actions that violate the rights of others.

Given the inportance that Nozick and other libertarians attach to the inviolability of individual rights, it would be inconsistent for those theorists to adopt a position that would allow border crossings whenever the transgressor was willing and able to pay compensation. Such a position would effectively give individual rights the same status as any other commodity, that is, something available for purchase by anyone willing and able to pay the price. A position that left the decision whether to cross the boundaries of another to the transgressor provided that he pay compensation would violate the libertarian injunction against treating individuals as ineans.

This is not to say, however, that punishment is the morally necessary response to all border crossings. Rather, a libertarian theory would want to allow individuals to consent to certain border crossings in return for negotiated coinpensation. Nozick niight also allow border crossings where prior negotiations were not possible, but the victim would have agreed to open his borders and to receive compensation

40. See text accompanying note 36 supra. 
had prior negotiations taken place. ${ }^{41}$ The term "subjunctive conditional" will be used to refer to this concept.

The argument we are constructing would thus focus on the position that a victim would take with regard to any proposed transgression of his boundaries. It would treat the individual as an end rather than merely as a means, because his rights would not be subject to compulsory acquisition by the highest bidder. In effect, the subjunctive conditional would require the victim's tacit permission.

Reconstruction of Nozick's argument in this fashion facilitates an account of his arguinent from fear that is consistent with his overall thesis. The decision whether to allow border crossings must rest with the victim. Similarly, the decision whether to punish or extract compensation must rest with the victim. ${ }^{42}$ In the context of Nozick's theory, these decisions will rest with the state because the state represents its members in matters pertaming to the enforcement of their rights. ${ }^{43}$

Deliberations on the question whether to punish or extract compensation for border crossings may take into account interests involved besides those protected by the Lockean rights. The question calls for a policy decision that may take into account considerations that would otherwise be inappropriate. The decision to prohibit may be based on utilitarian considerations, such as the avoidance of general fear. These considerations may enter the decisionmaking process without violating the rights of transgressors, because persons who cross the borders of others have no right to treat their victims as ineans by violating their rights and then paymg compensation. Thus, by focusing first on actions that violate the rights of others, this argument from fear may use utilitarian considerations without violatimg hibertarian principles. ${ }^{44}$

41. R. Nozick, supra note 25 , at $71-73$. We note that Nozick does not actually allow the subjunctive conditional for fear-producing acts. "Which ones then may be done without the victim's prior consent provided compensation is paid afterwards? Not those producing fear. . . ." Id. at 72 .

42. Of course, the victim must justify his decision and will be limited in his choice of response by the constraints of the libertarian theory.

43. See note 31 supra.

44. While this restructured argument achieves consistency with Nozick's moral theory, it does so at the cost of depriving the concept of general fear of any great practical value. The subjunctive conditional requirement supposes that the amount of compensation paid is that which would have been agreed to if negotiations had preceded the violation. It seems, however, to be true that fear always pales in hindsight but assumes mammoth proportions in expectation. Clearly, if negotiations precede the border crossing, the amount of compensation required for agreement by the victim will be very large, so large in fact that very few individuals could afford the price. That being the case, we should expect very few "subjunctive conditional" rights violations to occur. However, if these few subjunctive conditional violations are the only ones tolerated by the state, and if general fear is occasioned by beliefs about the sorts of violations that the state will tolerate, then it is difficult to explain why there should be any substantial general fear.

The explanation must derive from the implausibility of attributing general fear to beliefs about the state's tolerance for certain types of violations. We are fearful when we believe that we 
IV

\author{
The Criteria for Minimal Adequacy and the \\ CONCEPT OF FEAR
}

We have argued that a moral justification for the tort/crime dis-

are likely to suffer an injury. But this likelihood depends on the total number of injury-producing acts, not on the number of such acts that are allowed. And, in the absence of a perfect system of enforcing compensation, the former number will exceed the latter. Thus, there may be great general fear despite the fact that the state will allow only a small number of rights violations.

Nozick's attribution of general fear to beliefs about the system's tolerance rather than to beliefs about the total number of such acts is rather puzzling. His reasons become clear only upon reconsideration of Nozick's overall program: demonstration that the minimal state can come into existence without violating the rights it purports to protect. This program required that the state prohibit the private enforcement of rights, since even a minimal state must have a monopoly on the use of power. But Nozick could not simply deny the right to enforce one's own rights, since that right is assumed within his libertarian framework.

Nozick attempted to escape this dilemma by suggesting that actions could be prohibited, even though the actor would normally have a right to commit them, if those actions are risky and fearproducing. Private enforcement of rights falls within this sphere of actions because of its potentially unreliable procedures. But the question remains as to how Nozick can justify this suggestion without violating his libertarian constraints.

It should be recalled that our reconstructed account of Nozick's argument from general fear allowed punishment only in cases that involved border crossings; hence, utilitarian considerations would come into play only in determining the appropriate response to the wrongdoer. This account justified punishment and overcame the prima facie prohibition against needless suffering but did not justify prohibiting acts that were not border crossings. Thus, our reconstructed view will not justify the move to the minimal state, because it does not justify prohibition of private enforcement of rights. Such enforcement cannot itself be a rights violation, and therefore considerations of utility cannot come into play.

Nozick's attempted justification for the prohibition against private enforcement of rights can only be understood if the victims of the general fear occasioned by such private enforcement are treated as victims of border crossings. If the production of general fear is viewed as a border crossing, then it must be redressed in some way. As we have demonstrated, however, it cannot be compensated. On the libertarian view, therefore, the border crossing must be prohibited. Of course, since general fear, in Nozick's view, is produced by the policies of the state, then the state, as transgressor, must be prohibited from maintaining those policies. Thus, Nozick's reasons for attributing general fear to the policies of the state become clear: that attribution is necessary in order to justify the state in prohibiting private enforcement of rights. If the state allows private enforcement, it will itself produce general fear. The state will itself be violating the side constraints of its members, and therefore must prohibit private enforcement. If general fear is caused merely by the knowledge of the total number of fear-producing acts that occur, the state can have no justification for prohibiting private enforcement and thus cannot come into existence without violating the rights of those who wish to enforce their own rights.

This interpretation may also clarify what Nozick had in mind in the following passage:

The principle of compensation requires that people be compensated for having certain

risky activities prohibited to them. It might be objected that either you have the right to forbid these people's risky activities or you don't. If you do, you needn't compensate the people for doing to them what you have a right to do; and if you don't, then rather than formulating a policy of compensating people for your unrightful forbidding, you ought simply to stop it. In neither case does the appropriate course seem to be to forbid and then compensate. But the dilemma . . . is too short. It may be that you do have a right to forbid an action but only provided you compensate those to whom it is forbidden.

R. Nozick, supra note 25 , at 83 . This passage can be understood only if we recognize that the prohibition of private enforcement of rights, on the interpretation given above, involves a confict between rights. Thus, the right to prohibit follows from the fact that in such a conflict one of the 
tinction unust contain three eleinents: a moral theory, interests to be protected, and an argument showing that those interests may be protected by criminalization within the constraints of the moral theory. In the preceding section, we showed how the concept of fear developed by Nozick could operate in a justification based on his libertarian moral theory. In this seetion, we will explore the use of the concept of fear in possible alternative moral justifications meetimg the criteria for miniinal adequacy. We will also consider whether fear is an emotional state that is unique in its usefuhress for such justifications.

\section{A. Fear as an Interest to be Protected}

Nozick treats fear as the defining characteristic of actions that may be prohibited on pain of punishment. He does not, however, explore the nature of fear in a way that indicates the reason for its central role in his theory.

Perhaps its role is due simply to the fact that fear is intrinsically unpleasant and intrusive on the hife of an individual. Alternatively, or additionally, fear may be inportant because of its social consequences. Social interaction depends upon the predictability of others' behavior and on feelings of security. Constant fear may cause an individual to avoid all social transactions that are not absolutely essential to his survival, thus impoverishing his life by depriving it of human relationships. Without a secure expectation that others will refrain from actions that he fears, an individual lacks the degree of autonomy necessary for social enrichment. For these reasons, we may view freedom from fear as a crucial interest to be protected. Production of fear may be the defining characteristic of actions to be criminalized within a variety of inoral justifications for the tort/crime distinction. Empirical problems remain: clarification of the things people fear is required, as is a inethod of ineasuring fear. Although these problems exist, we know enough about the concept of fear to show how it could function in justifications other than that suggested by Nozick.

\section{B. Fear in Alternative Moral Justifications}

The concept of general fear may be useful independent of its libertarian origins. Since states of fear and anxiety have negative utility, the utilitarian noral theory will offer grounds for the prohibition of fear-

rights must yield. Compensation must then be paid to redress the rights that have given way. Thus, private enforcement can be prohibited only upon payment of compensation. Unfortunately, this quasi-libertarian argument masks a utilitarian argument. The "uncompensated victims" of general fear, as we have shown, cannot be classified as victims at all, because the production of general fear is not a rights violation. The welfare of these persons is thus a purely utilitarian consideration. 
producing actions. We may thus view the matter from the standpoint of the general welfare: even im those cases where the cost of prohibiting fear-producing behavior outweighs the benefit of avoiding the specific harin caused by that behavior, the disutility inherent im general fear may alter the balance. For exainple, if a society placed a very high value on the inamtenance of one's good naine, the meinbers of that society might be fearful of slander. There would be disutility mvolved in prohibiting slanderous statements because such a prohibition could infringe on freedom of speech. If the question were simply whether a person's interest in his good naine outweighed society's interest in free speech, his interest unight lose. However, if society's general fear of slander were added to the balance, prohibition of slanderous acts might appear optimific.

Still, as has been suggested above, most of us are neither strict utilitarians nor thoroughgoing hbertarians; our moral outlook incorporates concern both for the general welfare and for the rights of individuals. We would, im fact, reluctantly sacrifice an innocent individual if the result were to save an overwhelıning number of others. In times of great crisis, such as war, we feel compelled temporarily to set aside our private lives for the sake of the general welfare. Yet, we also feel that we have a right to pursue our own projects and plans for life without constant attendance to the utilitarian calculus.

Most moral dileinmas that confront us are not readily resolved; all involve the difficulty of reconciling individual rights with each other, or witl the general welfare. It is impossible in inany cases to satisfy both, but each reinains deeply entrenched in our moral outlook. The tension between these conflictimg concerns exists because we lack a decision procedure that will determine and justify our preference of one over the other. That is, there is no overriding moral theory incorporating both concerns that will tell us how much utility nust be gained or disutility avoided in order to justify sacrifice of mdividual rights.

Yet we should not exaggerate the difficulties of the conflict between the fundamental moral primciples of libertarianisin and utilitarianism. Within the framework of moral justification based on either moral theory, the arguinent from general fear can function as an organizing concept that allows us to marshal conflicting considerations and gather the einpirical evidence necessary to justify a decision. Decisions made in the absence of such a framework appear arbitrary; without moral reference points, the function of concepts like fear and harm is unclear.

In many cases, arguments from general fear would produce identical results under any of the three moral theories under consideration. A libertarian would prohibit an action if it constitutes a rights violation 
and is also productive of general fear. If the action produces only slight anxiety, it might be allowed if compensation were paid. A utilitarian would not require that the action prohibited be a rights violation, for questions of rights are not relevant im his moral theory. A utilitarian would prohibit a fear-producing action if the disutility it produces outweighs the utility of allowing the action. A theorist concerned for both individual rights and the general welfare would not require a rights violation as a condition precedent to prohibition, but would require substantial disutility, since prohibition involves an interference with individual rights.

Some examples inight demonstrate how the argument from general fear might operate in relation to various moral theories. Actions like inurder, rape, and assault would be prohibited under any moral theory. Eacl of these acts involves a violation of the victin's individual rights, and knowledge that they were allowed, even on payment of compensation, would produce great general fear. The two requirements of the libertarian would thus be met. For the utilitarian, it would be sufficient that these actions produce general fear resulting in decreased utility.

Theft presents a more difficult case. Clearly, theft is a violation of the victim's right to property, but does theft produce general fear? This is an empirical question upon which the decision to prohibit depends, whatever the moral theory.

Defamation is a case in which the results might vary depending upon the inoral theory. For a libertarian, the initial question will be whether a right to an unsullied reputation can be derived from the Lockean rights. If not, then a libertarian could not justify prohibition of defamatory matter. For a utilitarian (as for a libertarian who had established a right to a clear reputation) the question would remain whether allowance of defamation is productive of general fear. The utilitarian would then have to consider the degree of general fear produced to determine whether prohibition would optimize utility.

Thus, the concept of general fear can function as an interest to be protected within justifications of the tort/crime distinction based on a nuinber of moral theories. Its elucidation assists in determining the particular rules governing criminalization of certain wrongful acts. While full adequacy of the justifications for particular prohibitions will depend upon the production of empirical data, it is clear that the concept of fear, within the context of the criteria for minimal adequacy, can help to formulate justifications that are formally correct. 


\section{The Function of Anger in a Moral Justification for the Tort/Crime Distinction}

The elucidation of a central role for fear in various moral justifications for the tort/crime distinction may lead us to consider whether any other emotional states can serve in a similar fashion. One einotion that suggests itself as potentially useful is anger. We will therefore explore the outlines an argument from anger might take.

What is the nature of an interest in being free from anger? We might draw on our analysis of fear to conclude that being in a state of anger is intrinsically unpleasant and intrusive on the individual. Alternatively, we might turn to the social consequences of anger-producing actions. A person in a state of anger tends to focus on the subject of his anger, and unless the anger is defused by an apology, explanation, or solne form of redress, it can grow into an obsession that blocks the individual's ability to enjoy the full range of human experience. The individual may withdraw from social interaction. Alternatively, he may become socially disruptive. Anger activates aggressive impulses while impairing the rational faculties that would normally control the aggression. In the heat of anger a person may take revenge on the object of his anger. His attack may in turn provoke retaliation by his victim or by observers who are ignorant of the reasons for the attacker's anger or who consider his response excessive. This can lead to escalation and widening of the conflict, with serious socially disruptive results. Thus, another possibility is that the interest in preventing angercausing actions derives froin a desire to prevent others froin responding to those actions by committing wrongs themselves.

We should point out that not all anger-producing actions will be significant. Since the interest in being free from anger focuses on the likelihood of violent or antisocial response to anger-producing actions, only those actions that provoke such responses could be prohibited under any moral theory. Actions that cause only trivial, isolated, or passive anger would be dealt with, if at all, by methods other than punishment.

In addition, of course, the relevant moral theory would himit the recourse to punishment as a response to anger-producing actions. Thus, under a libertarian theory, only those anger-producing actions that constituted border crossings could be punished. A utilitarian, on the other hand, would look to the degree of disutility involved in the angry response to an action to determine whether it could be punished.

It is the inoral dimension to this arguinent from anger that distinguishes it from sociological arguments. Einile Durkheim, ${ }^{45}$ for exain-

45. E. Durkheim, The Division of Labor in Society 70-110 (1933). 
ple, distinguishes torts from crimes on the basis of the reaction of the social audience. He identifies crimes by the passionate reactions they provoke in members of the coinmunity. These reactions are produced, he says, because crimes breach seriously and intensely held beliefs found in the collective conscience of the community. ${ }^{46}$ This is a descriptive account of crime and as such is morally neutral. The response of the community unay be inorally justifiable, or it may be merely an arbitrary reaction to eccentric behavior by a group whose solidarity is based on likeness. By contrast, our account of anger is normatively based. It shows how, by reference to a moral theory, anger inay function to justify the decision to prohibit. It adds a moral dimension to Durkheim's account while it is buttressed by his empirical findings. Durkheim has described the phenomenon of crime in terms of a passionate reaction. We base our argument for prohibition on this reaction and show how it can be morally justified.

Indeed, other empirical phenomena lend plausibility to the argument from anger. The historical development of the criminal law supports our arguinents about the consequences of leaving the victims of anger-producing actions to arrange private redress through compensation. Pollock and Maitland describe how the King's Peace was used in England to bring order to a situation in which blood-feud and outlawry had come to disrupt social life. ${ }^{47}$ Of course, we would not claim that this situation was the sole, or even the major motivating force for the institution of the King's Peace, ${ }^{48}$ but this historical event does show that to renit the victims of anger-producing actions to their private

46. Id. at 73 .

47. 2 F. Pollock \& F. Maitland, The History of English Law 448-67 (2d ed. 1968). Prior to the twelfth century, the English law of crimes was largely a matter of compensation between individuals and thus was almost identical in substance to tort law. Where the criminal actor was unable or unwilling to pay the price of his misdeeds, the matter could become the subject of feud or outlawry. This state of affairs was dramatically changed during the twelfth century. The criminal jurisdiction of the King was extended from a very limited number of special situations to all people, places, and times through the device of the King's Peace. Id. at 463-64.

48. Undoubtedly, one of the motivating factors in extending the King's jurisdiction was monetary. Criminal jurisdiction was a source of revenue and political patronage. Id. at 453. Pollock and Maitland suggest some other reasons for the extension. Id. at 462 . But there is enough evidence to say that the system of compensation and private enforcement had become unworkable and so socially disruptive by the twelfth century as to facilitate the spread of the King's Peace. Pollock quotes the Chronicle at the death of Henry 1, when the King's Peace was suspended: "Then there was tribulation soon in the land, for every man that could forthwith robbed another." F. POLLOCK, OXFORD Lectures 87 (1890). Pike is more extrcme, and cites no evidence for his contention that "[c]rimes in those days, and for many a generation afterwards, were committed wholesale. . . . [M] ere crimes of violence . . . were so common and so essential a characteristic of the age that no attempt can be made to estimate their number . . . " $1 \mathrm{~L}$. PIKE, A History OF CRIME IN ENGLAND 110 (1873). We should be careful of exaggeration in these claims in an age that is unaccustomed to the intricacy of feud and compensation for criminal conduct. It may be that the social norms governing this behavior were quite strong and only broke down as kinship ties became attenuated. See 2 F. Pollock \& F. MaITLAND, supra note 47, 
remedies can produce the undesirable consequences that we claim morally justify the prohibition of these types of conduct.

Other empirical data exists for this assertion. Lawrence Friedman argued that the incidence of vigilante groups in nineteenth-century America was due to the authorities' failure to deal adequately with those who had offended the community's sense of justice. ${ }^{49}$ Contemporary events, including the mcidence of violence in gas lines and a recent riot in San Francisco when a defendant was acquitted of murder in a highly publicized double-killing case, show that our arguments about the consequences of allowing certam anger-producing actions are by no means implausible.

\section{CONCLUSION}

Examination of various justifications for the tort/crime distinction in light of our criteria for mimimal adequacy has elucidated the deficiencies of those theories. However, these criteria have also pointed the way for development and assessment of more successful justifications. The criteria help to identify questions remaining to be addressed and to uncover the often conflicting rationales underlymg the distinction between torts and crimes. We hope that this discussion will stimulate debate on this neglected issue and help to focus arguments concerning the proper distinction on the same questions. In light of the very serious consequences of classifymg conduct as criminal, our strongest hope is that moral justification will not remain the subject of academic debate, but will inform the actual categorization of conduct as crimmal or tortious.

at 462. See also Newman, Law and Economy im Pre-Industrial Societies 153-59 (1979) (unpublished Ph.D. Thesis, University of California, Berkeley).

49. L. Friedman, A History of American LaW 253 (1973). 